\title{
Soil Loss Prediction on Mobile Platform Using Universal Soil-Loss Equation (USLE) Model
}

\author{
Supli Effendi Rahim ${ }^{1, *}$, Ahmad Affandi Supli ${ }^{2}$, and Nurhayati Damiri ${ }^{1}$ \\ ${ }^{1}$ Agrotechnology Department, Agriculture Faculty, University of Palembang (UNPAL), 30139, \\ Palembang Indonesia. \\ ${ }^{2}$ School of Multimedia Technology and Communication, Universiti Utara Malaysia (UUM), 06010 \\ Sintok Kedah, Malaysia. \\ ${ }^{3}$ Agrotechnology Department, Agriculture faculty. University of Sriwijaya (UNSRI), 30862, \\ Indralaya, Ogan Ilir, South Sumatra Indonesia.
}

\begin{abstract}
Indirect method for soil loss predictions are plentiful, one of which is Universal soil-loss equation (USLE) model. Available technology in mobile applications prompted the authors to develop a tool for calculating soil loss for many land types by transforming the USLE model into smart mobile application. The application is designed by using simple language for calculating each and every factor and lastly summing up the results. Factors that are involved in the calculation of soil loss are namely erosivity, erodibility, slope steepness, length of slope, land cover and conservation measures. The program will also be able to give its judgment for each of the prediction of soil loss rates for each and every possible land uses ranging from very light to very heavy. The application is believed to be useful for land users, students, farmers, planners, companies and government officers. It is shown by conducting usability testing using usability model, which is designed for mobile application. The results showed from 120 respondents that the usability of the system in this study was in "very good" classification, for three characteristics (ease of use, user satisfaction, and learnability). Only attractiveness characteristic that falls into "good" classification.
\end{abstract}

\section{Introduction}

Soil is a natural resource which can be utilized for agricultural purposes [1]. Two main functions of soil are namely as a nutrient sources for plants, and as the place where the roots of plants are anchoraged. According to Havlin et al. [2], soil is a dynamic material that always experiences changes both due to the inner materials contained in the soil, as well as due to the material coming from outside the soil. Those changes affect the productivity of soils. At the time where the productivity decreases, the damage of the soil is occurring.

\footnotetext{
*Corresponding author: sup_effendi@yahoo.co.id
} 
Soil erosion is one of the important processes that cause soil damage. Erosion is simply the movement of material from one place to another by certain media such as running water, rainfall, wind, etc. Movement of soil from a place to another cause a number of unwanted impacts namely the openness of a land and the nutrients that are needed by plants disappear as part of the nutrients are eroded. Meanwhile, in places where the eroded soils that are sedimented cause disturbances of waterways or canals, if it is sedimented in rivers and lakes they may cause the decline in water surface quality [3, 4]. Nonetheless, Rahim [1] stated that sedimentation derived from erosion in upper parts can cause the increase of soil fertility in the lower parts of certain areas.

Knowing the rate of soil erosion in a given land is important for apart from knowing the amount of soil being eroded, the rate is useful in finding the solution for the problem through programs of prevention, rehabilitation and control. Such programs require data from soil erosion predictions. Soil erosion predictions can be conducted both direct and indirect methods. Predicting soil loss indirect means is difficult to do as it is time consuming. Indirect method for soil loss predictions are plentiful, one of which is USLE (Universal soil-loss equation). Apart from its weaknesses, the USLE model is widely used and so far it can produce reasonable data for land use planning.

According to Suripin [3], USLE is designed for long term prediction for soil erosion that is taking place in an area. The equation can also predict the soil erosion taking place in non-agricultural lands. However, the equation cannot be used to predict the sedimentation and cannot calculate sediments from gully erosion, river bank erosion and river bed erosion. The main reason why USLE is widely used is because the model is relatively simple and parameter inputs for the model are relatively easy to derive.

Prediction model for soil erosion using USLE is an empirical model that is taking into account a number of factors namely rainfall, soil characteristics and management of the land as well as of the plant. In a book written by Rahim [1], it is clearly described that the erosion rate prediction for an area can be conducted manually by calculating each and every factor that contribute to the eroding soils taking place in a given area.

The availability of mobile application that is most prevalent in the world nowadays prompted the authors to develop more quickly and practical in calculating soil loss that may occur in an area. This paper focuses on the development of a mobile application as a tool for calculating of factors that contributes to the soil erosion taking place in an area. This application is equipped with a very useful program, especially for the students of Faculty of Agriculture, Faculty of Technology - Civil engineering department, and Faculty of Forestry. This paper tries to describe the use mobile applications as a practical and fast tool for calculating soil erosion taking place in given areas.

The study foresees the need for the improvement in styles for calculating the soil erosion taking place in areas that is planned for certain land uses. The tool can offer recommendations for better management for a given land by knowing the factors that need proper correction and treatments as to reduce soil erosion that may occur during the utilization of the lands for various uses.

\section{The framework for universal soil loss equation}

Soil erosion model is the describing mathematically the processes of detachment, transportation and deposition of soil particles on the surface of a land. There exist many erosion models which were developed, namely USLE, and several other empirical models such as Revised Universal Soil Loss Equation (RUSLE), Modified Universal Soil-Loss Equation (MUSLE), which were developed from the concept of USLE itself. One of the 
physical model after USLE is called Griffith University Erosion System Template (GUEST) [5, 6].

Erosion model USLE has made possible planners to predict soil erosion taking place in any given land at certain slopes, at certain rainfall patterns, for a number of soil types and the implementation of conservation measures. USLE was designed for long term soil erosion prediction. The equation can also predict the soil erosion in many land types [7].

In calculating the hazard of soil erosion in a given land the factors need to considered are rainfall, length of slope, slope steepness, soil characteristics, land cover and conservations measures. Main factors for erosion to take place are rainfall and the existence of runoff. With the factors, the rate of erosion can be determined with USLE that was firstly developed by Wischmeier and Smith [8], as also narrated by Rahim [1].

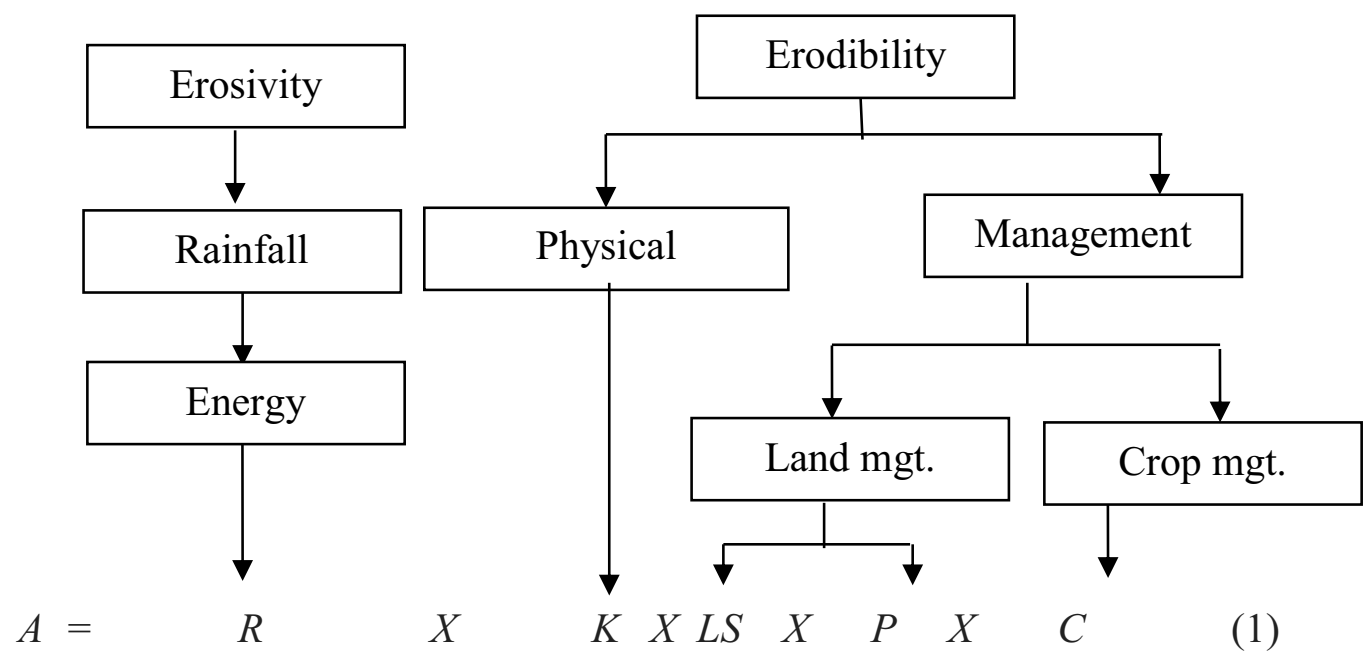

where: $\mathrm{A}=$ Annual eroded soil (tonnes/ha)

$\mathrm{R}=$ Erosivity

$\mathrm{K}=$ Erodibiity

LS $=$ Length and steepness of slopes

$\mathrm{P}=$ Conservation measures

$\mathrm{C}=$ Cropping management

In our study, erosivity factor is calculated using formula:

$$
R=6.119(R A I N)^{1.21}(D A Y S)^{-0.47}(M A X P)^{0.53}
$$

where: $\mathrm{R} \quad=$ Average monthly Erosivity index

RAIN $=$ Average monthly rainfall $(\mathrm{cm})$

DAYS $=$ Average monthly rain days

MAXP $=$ Maximum rainfall in 24 hours in the mentioned month

Erodibility factor is calculated using the following formula:

$$
100 K=\left(2.1 M^{1.14}\right)(12-O M)+4.20(s-2)+3.23(p-3)
$$

where: 
$\mathrm{K}=$ Soil erodibility

$\mathrm{OM}=$ Organic matter $(\%)$

$\mathrm{S}=$ soil structure code

$\mathrm{P} \quad=$ permeability of soil code

$\mathrm{M}=\mathrm{M}$ value can be also estimated if only known the soil texture

Slope length factor is defined mathematically as follows:

$$
L=(l / 22,1)^{m}
$$

Slope Steepness is defined mathematically as:

$$
S=\left(0.43+0.30 s+0.04 s^{2}\right) / 6.61
$$

where: $\mathrm{S}=$ actual slope steepness (\%)

Land cover factor shows the overall effect of vegetation factor, soil surface condition, mulch, and land management which affect soil loss. The following table shows the values of $\mathrm{C}$ factor.

Spesific conservation measures have been made for the soils in many places. In Java such values have been determined.

\section{Application for soil-loss prediction}

Attempts to mobile applications for assessing land suitability conducted by Rahim et al. [9] have proved that such a simple and practical means to assess the suitability of the land is possible. In the current work, authors tried to use the principle to calculate the rate of soil loss from any given land uses. Since all land users always find it difficult to do when dealing with large amounts of data coming from the land quality of laboratory analysis of the soil and the availability of data Geo-physics and climate throughout Indonesia and in the world. What is important here is that much remains to be done when dealing with planning and monitoring of the soil loss rates of land uses.

Approach and soil loss calculation methods traditionally applied by land users no longer can be widely recommended. Indonesian government, in this case, the Department of Agriculture, can no longer be silent without giving a quick solution to provide a tool for planners to calculate rates of soil erosion rates of any given land. Authors, with the help of sponsors, will complete in one year or over a program that is friendly to the tablet, apple or windows that serve as a tool for calculating soil loss rates of given land uses in agricultural practices in general. This is very needed by farmers in remote areas of Indonesia.

Results of screenshot of the application can be seen at the figures below (see Figure 1 and Figure 2) : 


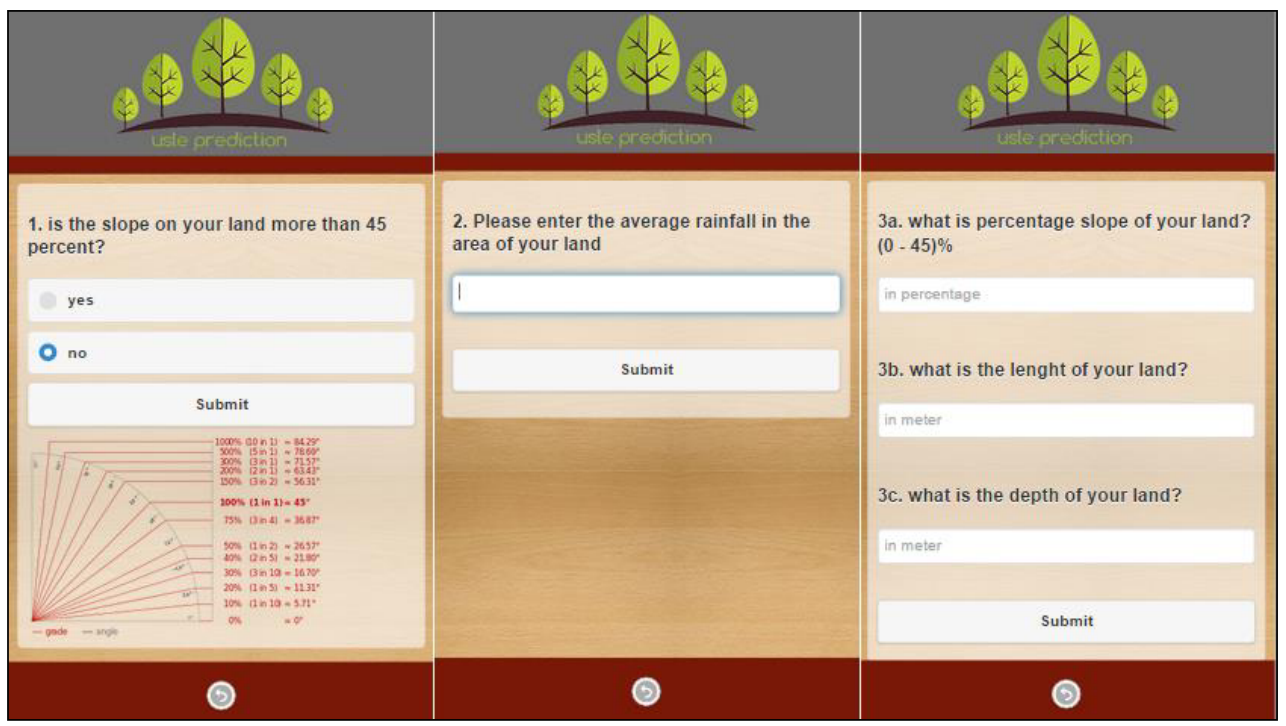

Fig. 1. The usle app questions.
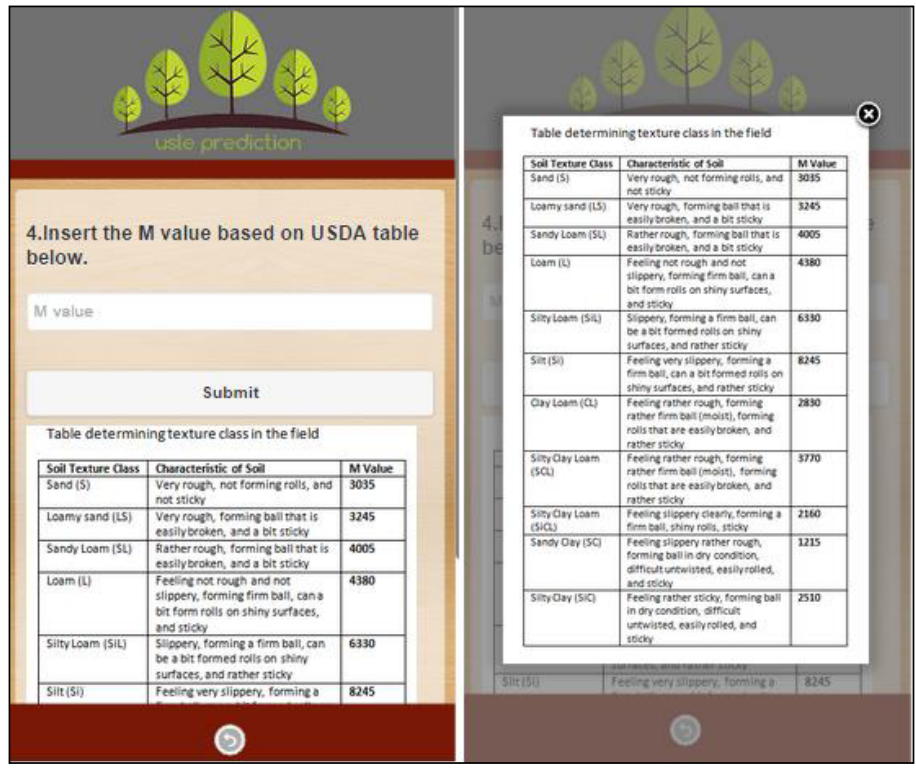

Fig. 2. Zooming feature.

The application is very straight forward and very easy to run in order to calculate the soil loss rates of users. The all variables in section 2 are all converted into 9 questions, which are easy to understand and have further detail description at several questions (see example in Figure 2), in a way to extract all information from a user. The zooming feature (Figure 2) is also provided in the app to see more clearly the additional description. Lastly, the result will be showed as a conclusion of soil loss rate (Figure 3). The conclusion for soil loss rate classification is given promptly (Figure 3) which shows factors that require treatments if the soil loss rate can be lowered to be allowable rates. 


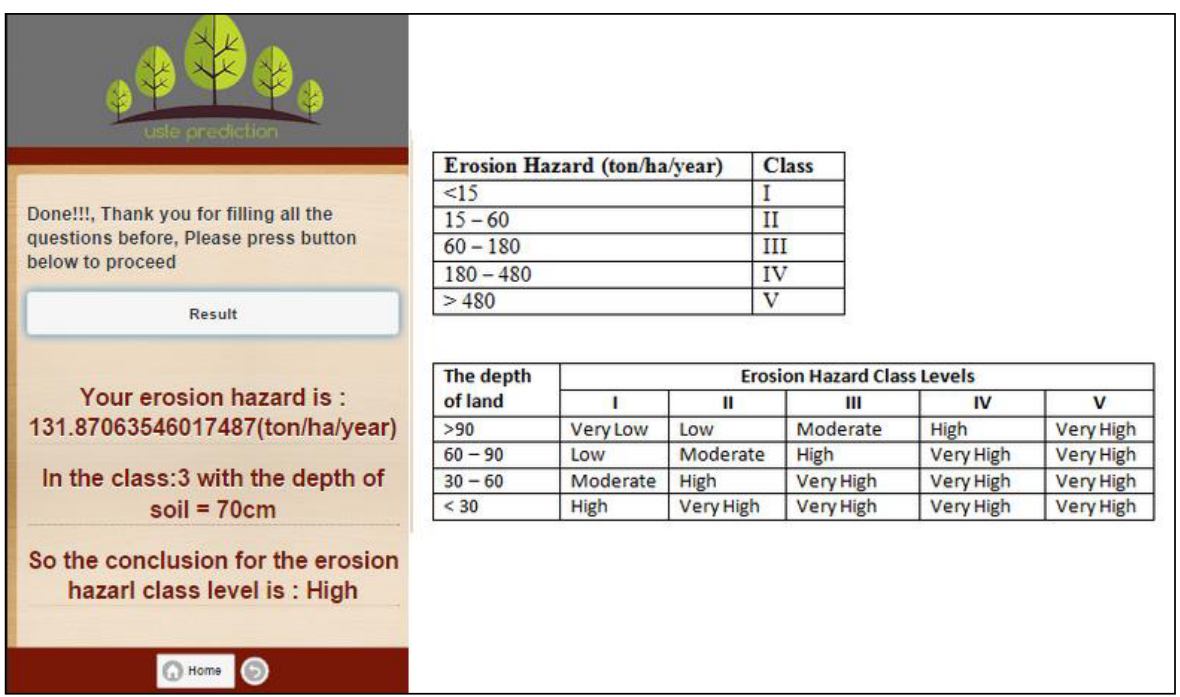

Fig. 3. The result of soil loss.

\section{Usability of the application}

In order to measure the system's usability in this study, the authors adapt a model developed by [10]. This model is chosen due to the usability measurement is specifically designed for mobile application. The usability characteristic in this model is categorized into four characteristic: ease of use, user satisfaction, attractiveness, learnability. The authors then measure all variables using descriptive analysis in SPPS software. Beforehand, convenience sampling was chosen, in which the respondents were obtained from any members of the population who are conveniently available to provide it [11]. Furthermore, [12] reported that in order to determine the sample size, there exist rules of thumb that could be used:

i. Sample capacities larger than 30 and less than 500 are suitable for most research.

ii. For simple experimental research with tight experimental controls, successful research can be achieved with samples as small as 10 to 20 in size.

Therefore, all in all, this study managed to gather 120 responses to be involved in the experiment. The demography is exhibited in table 1 below:

Table 1. Demography of respondents' status.

\begin{tabular}{|c|c|c|c|c|c|}
\hline \multicolumn{2}{|c|}{} & Frequency & Percent & Valid Percent & Cumulative Percent \\
\hline \multirow{4}{*}{ Valid } & lecturer & 34 & 28.3 & 28.3 & 28.3 \\
\cline { 2 - 6 } & employee & 30 & 25.0 & 25.0 & 53.3 \\
\cline { 2 - 6 } & students & 18 & 15.0 & 15.0 & 68.3 \\
\cline { 2 - 6 } & farmer & 38 & 31.7 & 31.7 & 100.0 \\
\cline { 2 - 6 } & Total & 120 & 100.0 & 100.0 & \\
\hline
\end{tabular}

All respondents were then required to fill the usability questionnaire that represents all the characteristics mentioned earlier. The questioner used the likert scale of 5 point (see Figure 4). 


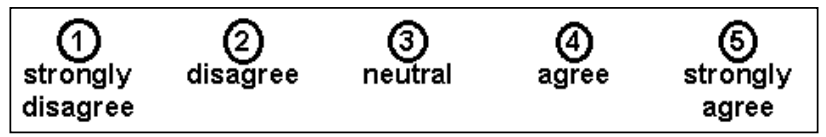

Fig 4. Linkert Scale 5-point

Then the all answers were analyzed by using descriptive analysis frequency. The calculation about mean, minimum, and maximum are analyzed. The results are shown as follows (see Table 2 and Table 3):

Table 2. Sub-characteristic Statistic Results

Descriptive Statistics

\begin{tabular}{|c|c|c|c|c|c|}
\hline & $\mathbf{N}$ & Minimum & Maximum & Mean & Std. Deviation \\
\hline Ease of use & 120 & 2.00 & 5.00 & 4.0750 & .60311 \\
\hline User satisfaction & 120 & 2.00 & 5.00 & 3.9611 & .65277 \\
\hline Attractiveness & 120 & 2.00 & 5.00 & 3.1972 & 1.15186 \\
\hline Learnability & 120 & 3.00 & 5.00 & 4.3375 & .62565 \\
\hline Valid N (listwise) & 120 & & & & \\
\hline
\end{tabular}

To interpret the results, the usage of five-point scale is used (see Table 3).

Table 3. The five-point Likert Scale.

\begin{tabular}{|c|c|}
\hline Gap & Classification \\
\hline $1.00-1.80$ & Poor \\
\hline $1.81-2.61$ & Fair \\
\hline $2.62-3.41$ & Good \\
\hline $3.42-4.42$ & Very Good \\
\hline $4.43-5.23$ & Excellent \\
\hline
\end{tabular}

Based on Table 3, it can be clearly seen that almost all characteristics in table 2 reached in the range between 3.19 and 4.34 points. Thus, the attractiveness's characteristic (3.19) falls into good classification. Nevertheless, the results for the other characteristics (ease of use, user satisfaction and learnability) are included in very good classification, which have mean score 4.07, 3.96 and 4.33 respectively. It can be concluded that all respondents have very good perspective in usability of the mobile application in general.

\section{Concluding remarks}

A new solution for soil loss calculation is simple to run by changing the USLE model in smart mobile applications as the appropriate tool in lieu of soil loss calculation system which is manual. This application is designed with a simple language for each factor and also by utilizing Based System (RBS), an algorithm rules. Soil loss calculation in this paper is begun by calculating the erosivity factor, followed by erodibility, slope length, slope steepness, land cover and conservation measures. The program is also designed to give the user classifications of rates of calculated soil loss of a given land and suggesting factors that require further treatments as to lower any high rate of soil erosion so that it will become allowable one. Computer-based program has been designed and implemented as a means of calculating soil loss of any given land use. This program will be designed according to cross platform technology such as tablet, apple and windows. The program urgently need 
officials to help them more easily manage their land for a better future. Last but not least, in terms of usability, the results showed that usability of the system are in "very good" classification for three characteristics: ease of use, user satisfaction, and learnability in which the all means of those are in the range between 3.96 and 4.33. Only the attractiveness dimension includes into "good" classification. In the future, this program will be designed according to the tablet as well as to other cross platform technology. The program is urgently needed by the users, farmers, companies, lecturers, students and government officials to help them more easily manage their land for a better future.

\section{References}

1. S.E. Rahim, Pengendalian Erosi Tanah dalam Rangka Pelestarian Lingkungan Hidup (Bumi Aksara, Jakarta, 2003)

2. J.L. Havlin, J.D.Beaton, S.L. Tisdale, W.L. Nelson, Soil fertility and fertilizers: An introduction to nutrient management. Upper Saddle River, NJ (Pearson Prentice Hall, 2005)

3. Suripin, Pelestarian sumber daya tanah dan air (Andi, 2002)

4. J.F. Boyle, A.J. Plater, C. Mayers, S.D. Turner, R.W. Stroud, J.E. Weber, J. Paleolimnol., 45, 199 (2011)

5. A.A. Millward, E.M. Janet, Catena, 38,109 (1999)

6. K. Subagyono, T. Vadari, R.L. Watung, F. Agus, Land management for controlling soil erosion at microcatchment sale in Indonesia (No. H037205) (International Water Management Institute, 2004)

7. K.G. Renard, G.R. Foster, G.A. Weesies, J.P. Porter, J. Soil Water Conserv., 46, 30 (1991)

8. W.H. Wischmeier, D.D. Smith, Predicting rainfall erosion losses-A guide to conservation planning (1978)

9. S.E. Rahim, A.A. Supli, N. Shiratuddin, Nurhayati Damiri, Z.S. Mukti, The International Joint Conference of Indonesia Malaysia Bangladesh Ireland (Banda Aceh Indonesia, 2015)

10. A.A. Ali. A framework for measuring the usability issues and criteria of mobile learning applications (Doctoral dissertation, The University of Western Ontario, 2013)

11. R. Bougie, U. Sekaran, Research methods for business: A skill building approach (Wiley, London, 2010)

12. J.T. Roscoe, Fundamental Statistics for the Behavioural Science (New York, Holt, 1975) 